\title{
Panicle Traits and Plant Height are Important Selection Indices to Enhance Productivity in Pearl Millet (Pennisetum glaucum L.R.Br.) Populations
}

\author{
K. Sudarshan Patil ${ }^{1,2}$, S.K. Gupta ${ }^{2}$, Kuldeep Singh Dangi ${ }^{1}$, \\ D. Shashibhushan ${ }^{1}$, M. Balram ${ }^{1}$ and T. Ramesh ${ }^{1}$ \\ ${ }^{1}$ College of Agriculture, PJTSAU, Hyderabad-030, Telangana, India \\ ${ }^{2}$ ICRISAT, Patancheru, Hyderabad-030, Telangana, India \\ *Corresponding author
}

\begin{tabular}{|c|c|}
\hline & B S T R A C T \\
\hline Keywords & \multirow{4}{*}{$\begin{array}{l}\text { The study was conducted to determine the correlation and path coefficients among the } \\
\text { yield and yield component characters in } 14 \text { parental lines and } 91 \text { hybrids of pearl millet } \\
\text { (Pennisetum glaucum L. R. Br), formulated by a diallel cross excluding reciprocals. Strong } \\
\text { and significant genotypic and phenotypic correlations were observed between grain yield } \\
\left(\mathrm{kg} \mathrm{ha}^{-1}\right) \text { with panicle girth }(\mathrm{cm}) \text {,plant height }(\mathrm{cm}) \text { and panicle length }(\mathrm{cm}) \text {. The path } \\
\text { analysis indicated that panicle girth }(\mathrm{cm}) \text { and plant height }(\mathrm{cm}) \text { had the highest direct } \\
\text { effects on grain yield. The days to } 50 \% \text { flowering, } 1000 \text {-grain weight }(\mathrm{g}) \text { and number of } \\
\text { productive tillers had the least direct effects on grain yield. The direct effect of panicle } \\
\text { girth }(\mathrm{cm}) \text { was greatly reduced by the negative indirect effects through days to } 50 \% \\
\text { flowering and } 1000 \text {-grain weight }(\mathrm{g}) \text {. Similarly, the direct effect of plant height was very } \\
\text { much influenced by the negative indirect effects of days to } 50 \% \text { flowering. The panicle } \\
\text { girth, plant height and panicle length in this study has been identified as selection indices } \\
\text { for obtaining good parental lines and hybrids in a pearl millet breeding program. }\end{array}$} \\
\hline & \\
\hline Arti & \\
\hline & \\
\hline
\end{tabular}

\section{Introduction}

Pearlmillet (Pennisetum glaucum L.R.Br.), known as bulrush orcat tail millet is also known as 'Bajra' in India. It is grown widely in the arid and semi-arid tropical regions in Indian subcontinent and African continent under the most adverse agro-climatic conditions where other crops like sorghum and maize fail to produce economic yields. In India, pearl millet is the third most widely cultivated food crop after rice and wheat. It is a rich source of iron and zinc. Apart from being a main staple food crop, its use for poultry feed is on the increase. It is also an important source of fodder and the only source of feed in dry months (Hash et al., 2003). It is grown on 9 million ha with an average productivity of $1,000 \mathrm{~kg} \mathrm{ha}^{-1}$ (Yadav and Rai, 2013). The ultimate aim in most plant breeding programs is the improvement in the productivity of grains as measured in terms of the yield per unit area. The possibilities of achieving this goal through genetic manipulation have been elucidated by evolving high yielding hybrids and varieties of pearlmillet in Asia and West Africa. These newly evolved varieties and hybrids owe their 
high yielding ability to a reconstruction of an ideal plant type. It is now widely recognized that the improvement in plant type can make a very significant contribution to a higher total grain yield.

The grain yields largely under subsistence farming are low (500-700 $\left.\mathrm{kg} \mathrm{ha}^{-1}\right)$. Low soil fertility, rain-fed farming characterized by erratic and inadequate rainfall, negligible external inputs, continued use of mostly unimproved cultivars with a low harvest index $(<20 \%)$ and the prevalence of diseases and insect pests being the major causes of low productivity. Grain yield character in pearl millet and as in all crop plants is quantitative in nature and is polygenically controlled. Selection based on grain yield character alone is usually not very effective and efficient. However, selection based on its component characters could be more efficient and reliable. Knowledge of the association between yield and its component characters and among the component characters themselves can improve the efficiency of selection in plant breeding. Owing to a complex situation, selection for an optimum advance on grain yield should be based on judiciously computed index. The correlation studies taken alone are often misleading and the actual dependence of grain yield on the correlated yield component characters needs confirmation, which can easily be untangled and unraveled by path coefficient analysis.

The path coefficient analysis is simply a standardized partial regression coefficient and as such, it measures the direct influence of one variable upon the other and permits the separation of correlation coefficients into components of direct and indirect effects.

Studies of correlation and path analysis were conducted in different crops such as in groundnut, by (Izgeet al., 2004), in sorghum, by (Ezeaku and Mohammed, 2006), Singh and Singh (1973), Bello et al.(2001), in cowpea by
(Oseni, 1994), and in rice by Kumar and Saini (1973). The present study was undertaken to study the correlations and path analysis in different pearl millet populations and their hybrids to develop a criterion for selection that could be effectively used for selecting the desirable genotypes or lines with high yield potential in the future.

\section{Materials and Methods}

Fourteen (14) pearl millet populations together with their 91population hybrids obtained from a diallel cross excluding reciprocals produced at International Crops Research Institute for the Semi-Arid Tropics (ICRISAT), Patancheru, Hyderabad, were used for the study. The experiment was conducted during rainy season of 2016 at three locations in Patancheru $\quad\left(18^{\circ} \mathrm{N}, \quad 78^{\circ} \mathrm{E}\right), \quad$ Professor Jayashankar Telangana State Agricultural University (PJTSAU), Regional Agricultural Research station (RARS), Palem $\left(17^{\circ} \mathrm{N}\right.$, $78^{\circ} \mathrm{E}$ ), and Jamnagar Agricultural University (JAU), Pearl millet research station, Jamnagar $\left(22^{\circ} \mathrm{N}, 70^{\circ} \mathrm{E}\right)$.

The experiment consisted of 105 treatments (14 parental lines +91 hybrids) laid out in alpha-lattice design with two replications. In each replication, the size of the plot consisted of 4 rows with a length of 4 meters. The spacing between and within the rows was maintained at $75 \mathrm{~cm}$ and $12-15 \mathrm{~cm}$, respectively. Seeds after germination were thinned down to one plant per hill after two weeks of sowing. A basal dose of $100 \mathrm{~kg}$ of di-ammonium phosphate (18\% N and $46 \% \mathrm{P})$ was applied at the time of field preparation and $100 \mathrm{~kg}$ of urea $(46 \% \mathrm{~N})$ was applied as top dressing in two-split dose at the stage of three weeks and five weeks after sowing. Trials were regularly irrigated to avoid any moisture stress. All the recommended agronomic practices were followed for raising good crop. 


\section{Data collection}

Data collection was done for the grain yield and seven yield component characters. The observations were taken on 15 random plants from each population for the traits likeplant height $(\mathrm{cm})$, number of productive tillers/plant, panicle length $(\mathrm{cm})$, and panicle girth $(\mathrm{cm})$. Other traits such as days to $50 \%$ flowering, grain yield, 1000-grain weight $(\mathrm{g})$ and dry stover yield data were recorded on plot basis. Further, data of grain yield and stover yield was converted to $\mathrm{kg} \mathrm{ha}^{-1}$.

\section{Data analysis}

Phenotypic and genotypic linear correlation coefficients were calculated for all the possible comparisons using the formula suggested by Falconer (1964). The correlation coefficients were partitioned into direct and indirect effects using the path coefficient analysis according to Dewey and Lu (1959). Data analysis was carried out using SAS v 9.4 software (SAS, Inc., 2017).

\section{Result and Discussion}

\section{Phenotypic and genotypic correlation}

The phenotypic and genotypic correlation coefficients between grain yield and its component traits are presented in Table 1. The genotypic correlation coefficient of 0.570 between grain yield with panicle girth and phenotypic correlation coefficient of 0.335 between grain yield with dry stover yield were among the highest values obtained in the present study. The correlation coefficients for most of the pairs of characters revealed the presence of strong positive genotypic association between grain yield with all the traits except for number of productive tillers. Moderate positive phenotypic association was found between grain yield with plant height, panicle girth and dry stover yield. The genotypic correlations were of higher magnitude than their corresponding phenotypic correlations, indicating a strong inherent relationship among the characters studied. This strong genotypic correlation over phenotypic correlations were reported in previous studies in pearl millet (Khairwal et al., 1999, Izge et al., 2006, Bhuri Singh et al., 2015 and Bhasker et al., 2017) and in Sorghum (Bello et al. 2001, Ezeaku and Mohammed, 2006).

Significant positive genotypic correlation between grain yield with days to $50 \%$ flowering (0.461) and significant negative genotypic correlation between grain yield with number of productive tillers was observed in the present study. On the contrary, Izge et al., (2006) and Bhuri Singh et al., (2015) found negative genotypic correlation between grain yield and days to $50 \%$ flowering and positive correlation between grain yield and number of productive tillers per plant. This difference might be due to use of more number of African based populations involved in the study, which are generally late flowering in nature, and differ in their adaptation to the changed environment condition in Indian subcontinent. However, most correlation studies reported no correlation between days to $50 \%$ flowering and grain yield (Chaudhary, 1992, Ezeaku and Mohammed 2006, Izgeet al., 2004).

The result also revealed the presence of positive and highly significant genotypic correlations of days to $50 \%$ flowering with plant height (0.909), panicle length (0.698), and dry stover yield (0.833). Negative and highly significant genotypic correlations were observed between days to50\% flowering with number of productive tillers (-0.809).In addition, number of productive tillers showed significant negative correlation with all the traits in both types of correlations. Whereas, plant height showed significant positive genotypic and phenotypic correlation with all the traits except for panicle girth. 
Table.1 Analysis of genotypic (above diagonal) and phenotypic(below diagonal) correlation coefficients for grain yield and yield components characters in pearlmillet combined three across locations

\begin{tabular}{|l|c|c|c|c|c|c|c|c|}
\hline & DFF & PHT & NPT & PL & PG & TKW & DSY & GY \\
\hline DFF & & $0.909 * *$ & $-0.809 * *$ & $0.698 * *$ & $0.160 * *$ & 0.096 & $0.833 * *$ & $0.461 * *$ \\
\hline PHT & $0.604 * *$ & & $-0.500 * *$ & $0.667 * *$ & 0.083 & $0.251 * *$ & $0.853 * *$ & $0.395 * *$ \\
\hline NPT & $-0.264 * *$ & $-0.214 * *$ & & $-0.467 * *$ & $-0.574 * *$ & $-0.543 * *$ & $-0.383 * *$ & $-0.367 * *$ \\
\hline PL & $0.479 * *$ & $0.538 * *$ & $-0.162 * *$ & & 0.023 & 0.108 & $0.657 * *$ & $0.409 * *$ \\
\hline PG & 0.093 & 0.103 & $-0.219 * *$ & 0.020 & & $0.731 * *$ & -0.098 & $0.570 * *$ \\
\hline TKW & 0.090 & $0.153 *$ & $-0.123 *$ & 0.038 & $0.502 * *$ & & -0.046 & $0.469 * *$ \\
\hline DSY & $0.537 * *$ & $0.641 * *$ & $-0.145 *$ & $0.384 * *$ & -0.016 & -0.013 & & $0.361 * *$ \\
\hline GY & 0.104 & $0.268 * *$ & $-0.143 *$ & 0.116 & $0.241 * *$ & 0.110 & $0.335 * *$ & \\
\hline
\end{tabular}

$*, * *$, Significance at $0.05,0.01$ levels of probability, respectively.

DFF: Days to50\% flowering, PHT: Plant height $(\mathrm{cm})$, NPT:Number of productive tillers/plant, PL: Panicle length(cm), PG: Panicle girth(cm), TGW: 1000-grain weight(g), DSY-Dry stover yield $\left(\mathrm{kg} \mathrm{ha}^{-1}\right)$, GY-Grain yield $\left(\mathrm{kg} \mathrm{ha}^{-1}\right)$

Table.2 Path coefficient analysis of grain yield [direct effects (diagonal) and indirect effects] with other yield components in pearl millet, combined across locations

\begin{tabular}{|l|c|c|c|c|c|c|c|l|}
\hline & DFF & PHT & NPT & PL & PG & TGW & DSY & $\begin{array}{l}\text { Genotypic } \\
\text { correlation } \\
\text { with GY }\end{array}$ \\
\hline DFF & $\mathbf{- 1 . 0 3 2}$ & 0.600 & 0.260 & 0.208 & 0.128 & -0.035 & 0.332 & $0.461 * *$ \\
\hline PHT & -0.938 & $\mathbf{0 . 6 6 0}$ & 0.161 & 0.198 & 0.066 & -0.093 & 0.340 & $0.395^{* *}$ \\
\hline NPT & 0.835 & -0.330 & $\mathbf{- 0 . 3 2 1}$ & -0.139 & -0.458 & 0.200 & -0.153 & $-0.367 * *$ \\
\hline PL & -0.720 & 0.440 & 0.150 & $\mathbf{0 . 2 9 8}$ & 0.018 & -0.040 & 0.262 & $0.409 * *$ \\
\hline PG & -0.165 & 0.054 & 0.185 & 0.007 & $\mathbf{0 . 7 9 7}$ & -0.269 & -0.039 & $0.570^{* *}$ \\
\hline TGW & -0.099 & 0.166 & 0.175 & 0.032 & 0.582 & $\mathbf{- 0 . 3 6 8}$ & -0.018 & $0.469 * *$ \\
\hline DSY & -0.859 & 0.563 & 0.123 & 0.196 & -0.078 & 0.017 & $\mathbf{0 . 3 9 9}$ & $0.361 * *$ \\
\hline
\end{tabular}

*, **, Significance at $0.05,0.01$ levels of probability, respectively.

DFF:Days to50\% flowering, PHT: Plantheight $(\mathrm{cm})$, NPT:Number of productive tillers/plant, PL: Paniclelength(cm), PG:

Paniclegirth(cm), TGW: 1000-grain weight(g), DSY-Dry stover yield $\left(\mathrm{kg} \mathrm{ha}^{-1}\right)$, GY-Grain yield $\left(\mathrm{kg} \mathrm{ha}^{-1}\right)$ 
Significant positive correlation of lower magnitude (0.409) was observed between grain yield with panicle length. The difference of opinion in the various studies undertaken by many authors could be attributed to the differences in the materials used and the prevailing weather conditions. Generally, the genotypic correlations showed more significant difference between pairs of characters than the phenotypic correlations. Significant and positive correlations between yield and other yield variables are quite desirable in plant breeding, because it facilitates the selection process. Similar observations were reported by Thangasamy and Gomathinayagam (2003), Izge et al., (2006), Sumanth et al., (2014) and Bhasker et al., (2017) in pearl millet and Rajni et al.,(1978), Bello et al., (2001), and by Aba and Obilana (1994), in various other crops.

\section{Path Coefficient Analysis}

The path coefficient analysis of yields and its components are presented in Table 2. The path coefficient analysis revealed that panicle girth and plant height gave the highest direct effect on total grain yield at 0.797 and 0.660 , respectively. The direct and indirect contributions by days to $50 \%$ flowering through most of the characters were negative. Number of tillers/plant had the positive indirect effect towards total grain yield/ha through rest of the other traits. Panicle girth had a very strong correlation with grain yield (0.57), there was high indirect effect through 1000 -grain weight $(0.582)$, with very low indirect effects through plant height (0.066) and panicle length $(0.018)$, whereas negative indirect effects were found through number of tillers/plant (-0.139) and dry stover yield (0.078 ). The highest indirect effect of 0.835 toward grain yield was found through days to $50 \%$ flowering and number of tillers/plant, while the minimum indirect effect of -0.859 was made by days to $50 \%$ flowering through dry stover yield. Higher indirect values could most likely be neutralized in most cases by the negative indirect effects via other characters and this can lead to their low and non-significant genotypic correlation with total grain yield. In that regard therefore, selection for such characters may not enhance yield improvement and are not to be encouraged.

Plant height, panicle length, panicle girth and 1000 -grain weight were also important yield determinant characters because of their positive and highly significant levels of correlations with yield. Plant height had a direct effect of 0.66 toward grain yield and indirect effects of $0.440,0.166$ and 0.054 through panicle length, 1000-grain weight and panicle girth respectively. Similarly, Izge et al., (2006) also found high direct effects and significant high positive correlations for plant height with grain yield. Panicle length exhibited the positive indirect effect through plant height (0.198) and the lowest indirect effect of-0.139 through number of productive tillers per plant. The correlation coefficient between panicle length and grain yield was also high. Panicle girth contributed highest positive indirect effect through 1000-grain weight (0.582), and low positive effects through plant height (0.066) and panicle length (0.018). On the contrary, Sumanth et al., (2014) found high direct effects for number of productive tillers and negative direct effects for plant height and panicle length. Bhasker et al., (2017) and Rakesh et al., (2015) reported high direct effects for fodder yield followed by panicle length, plant height, 1000-grain weight and number of productive tillers per plant on grain yield.

Panicle girth, plant height and panicle length appeared to be the prominent characters when selecting for grain yield in pearl millet, because of their highly significant genotypic and phenotypic correlations with grain yield. 
Thangasamy and Gomathinayagam (2003) and Bhuri Singh et al., (2015) reported these traits to be important for selection process to improve grain yield in pearl millet. These characters also had the highest direct effects on grain yield and high indirect effects through most of the other characters. This investigation therefore suggests that panicle girth, plant height and panicle lengthshould be given maximum consideration for total yield improvement as the appropriate selection indices. The selection procedure should be formulated so that the advance in one component is not jeopardized by the deterioration effect of the other.

\section{References}

Aba, D.A. and Obilana, A.T. 1994. Correlations in mass selected population of sorghum. East Afr. Agric. For. J. 60 (1): 45-50.

Anand Kumar and Andrews, D.J.1993. Genetics of quantitative traits in pearl millet: a review. Crop Sci. 33: 1-20.

Bello, D., Kadams, A.M. and Simon, S.Y. 2001. Correlation and path coefficient analysis of grain yield and its components in sorghum (Sorghum bicolor L. Moench). Nig. J. Trop. Agric. 3: 4-9.

Bhasker, K., Shashibhushan, D., Murali Krishna, K. and Bhave, M.H.V. 2017. Correlation and path analysis for grain yield and it components in Pearl millet [Pennisetum glaucum(L).R.Br.]. Bull. Env. Pharmacol. Life Sci., 6(1): 104106.

Bhuri Singh, Sharma, K.C. and Meena, H.K. 2015. Character association and path analysis of certain quantitative characters among parental lines and their hybrids in pearl millet. Agric. Sci. Digest. 35(2): 121-125

Chaudhary, M.S. 1992. Path analysis and correlation in high yielding mungbean varieties. ARC Training Report. 1-5.

Dewey, D.R.and Lu, K.H. 1959. A correlation and path coefficient analysis of crested wheat grass seed production. Agron. J. 51: 515-518.

Ezeaku, I.E. and Mohammed, S.G. 2006. Character association and path analysis in grain sorghum. Afr. J. Biotechnol. 5(14): 1337-1340.

Falconer, D.S. 1964. Introduction to quantitative genetics. Oliverand Boyd Ltd., London, W.I.

Hash, C.T., Bhasker Raj, A.G., Lineup, S. et al.2003. Opportunities for markerassisted selection (MAS) to improve the feed quality of crop residues in pearl millet and sorghum. Field Crops Research, 84: 79-88.

Izge, A.U., Alabi, S.O. andMaina, Y.T. 2004. Correlation and path analysis of pod yield and yield components of groundnut (Arachis hypogeae L.). J. Sustain. Agric. Environ. 6 (1): 15-21.

Izge, A.U., Kadams, M. andGungula, D.T. 2006. Studies on character association and path analysis of quantitative characters among parental lines of pearl millet (Pennisetum glaucum) and their $F_{1}$ hybrids in a diallel cross. Afr. J. of Agril. Res. 1(5): 194-198.

Khairwal, I.S., Rai, K.N., Andrew, D.J. and Harinarayana, G. 1999. Pearl millet breeding. Oxford and IBH Publishing Co. New Delhi. p 511.

Kumar, I. and Saini, S.S. 1973. Path analysis in short stature rice varieties. Indian J. Genet. Plant Breed. 33: 13-15.

Oseni, T.O.1994. Correlation and path coefficient analysis of height components on grain yield of cowpea (Vigna unguiculata L. Walp). 11:4347.

Rajni, R., Sharma, G.S. and Singh, R.B.1978. Path coefficient analysis of some yield and quality characters in normal and EMS-treated varieties of treated wheat. 
Indian J. Agric. Sci. 48 (11): 637-640.

Rakesh, G., Dayakar Reddy, T., Shashibhushan, D. and Bhave, M.H.V. 2015. Character association and path coefficient analysis for grain yield and its components in pearl millet [Pennisetum glaucum (L.) R.Br.]. Ecol. Environ. and Conser. 21(3): 1325-1330.

SAS Institute Inc. 2017. SAS/STAT® 14.1User's Guide. Cary, NC.

Singh, T.P. and Singh, K.B. 1973. Association of grain yield and its components in segregating populations of green gram. Indian J. Genet. Plant Breed. 33: 112117.

Sumanth, M., Sumathi, P., Kumari Vinodhana, N. and Sathya, M. 2014. Inter correlation and path coefficient studies for grain yield and its components in Pearl millet (Pennisetum glaucum
(L).R.Br.). Ann. of arid zone 53(1): 55-57.

Thangasamy, S. and Gomathinayagam, P. 2003. Genetic study of correlation and path analysis in Pearl millet. Ann. of Agri. Res. 24(4): 782-785.

Wright, S. 1921. Correlation and causation. J. Agric. Res. 20: 557-585.

Yadav, O.P., Rai, K.N. and Gupta, S.K. 2013. Chapter 12: Pearl millet: Genetic improvement for tolerance to abiotic stresses, in Improving Crop Productivity in Sustainable Agriculture (eds N. Tuteja, S.S. Gill and R. Tuteja), Wiley-Blackwell.

Yoshida, T. and Sumida, K. 1996. Mass selection and grain yield of improved population in pearl millet (Pennisetum typhoideum Rich.). Jpn. J. CropSci. 65:58-62

\section{How to cite this article:}

Sudarshan Patil, K., S.K. Gupta, Kuldeep Singh Dangi, D. Shashibhushan, M. Balram and Ramesh, T. 2018. Panicle Traits and Plant Height are Important Selection Indices to Enhance Productivity in Pearl Millet (Pennisetum glaucum L.R.Br.) Populations. Int.J.Curr.Microbiol.App.Sci. 7(12): 306-312. doi: https://doi.org/10.20546/ijcmas.2018.712.037 